\title{
TECTONIC EVOLUTION OF CONTINENTS IN THE PRECAMBRIAN
}

by

Brian F. Windley

The bulk of the earth's continental lithospheric plates was produced in the Precambrian, which constitutes about seven-eighths of geological time. To what extent did plate tectonic processes contribute to this early continental growth? This paper highlights some of the critical aspects of Precambrian evolution, particularly with regard to tectonics and magma provenance.

It is increasingly important for the Precambrian specialist to be aware of the lessons learned from studies of the MesozoicCenozoic fold belts because of the extensive constraints bearing on their mode of formation. It is also increasingly apparent that a great many Precambrian rocks are remarkably similar to their Phanerozoic counterparts (Windley, 1977). Before surveying the nature of Precambrian rocks and their problems, one must consider two of the most important constraints on Precambrian tectonic development: palaeomagnetism and heat.

\section{Palaeomagnetism}

The palaeomagnetic method allows the definition of apparent polar wander paths (APWP) which track the lateral movement of continents throughout the Phanerozoic. APWP, with loops and tracks of comparable shape and size, can be constructed as far back as $2600 \mathrm{Ma}$ ago (Fig. 1), implying that the continents drifted laterally during the Proterozoic on plates essentially as rigid as those of today (McElhinny, 1973).

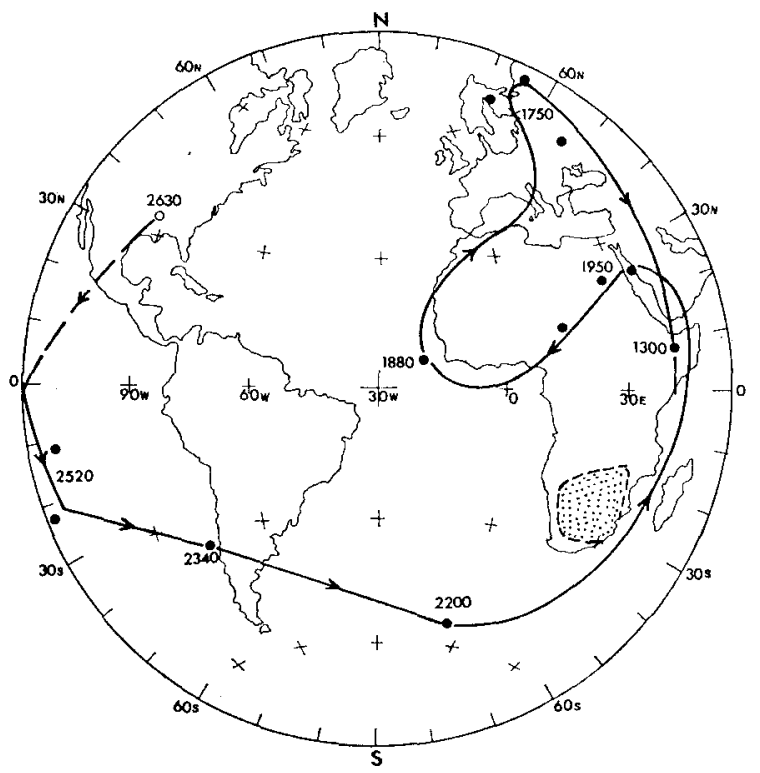

Figure 1: Precambrian apparent polar wander path for southern Africa (after McElhinny, 1973).

\section{Heat Production and Loss}

The concentration of radiogenic isotopes and consequent heat production was several times greater in the early Precambrian than it is at present. Today, about one-third of the earth's heat loss escapes by conduction through continental lithosphere, one-third by conduction through oceanic lithosphere, and one-third is used in generation and aging of new oceanic crust/lithosphere (Burke and Kidd, 1978). Also, about $45 \%$ of the earth's total heat is lost by the oceanic plate creation-subduction process (Bickle, 1978), and the oceanic crust cools about ten times faster than the continental crust.
Conduction is, in general, a very inefficient process of heat loss, and it cannot be increased substantially (to take account of the higher heat production in the past) or else the lower continental crust would undergo extensive partial melting and give rise to voluminous granites, for which there is no evidence in Archaean terrains. But the amount of heat dissipated by convection could have been higher if there had been an increase in either the total length of mid-oceanic ridges or the rate of plate production (Burke and Kidd, 1978).

Thus the only effective means of dissipating the higher heat production in the early Precambrian was accelerated tectonic activity. Bickle (1978) concluded that the rate of plate production was $18 \mathrm{~km}^{2} / \mathrm{yr} ., 2.8 \mathrm{Ga}$ ago, which compares with $3 \mathrm{~km}^{2} / \mathrm{yr}$. at present. This would necessitate a proportional increase in subduction and production of new calc-alkaline magmas derived by partial melting of the downgoing lithospheric slabs, which is consistent with the very high proportion of volcanic and tonalitic rocks produced between 3.8 and $2.5 \mathrm{Ga}$ ago.

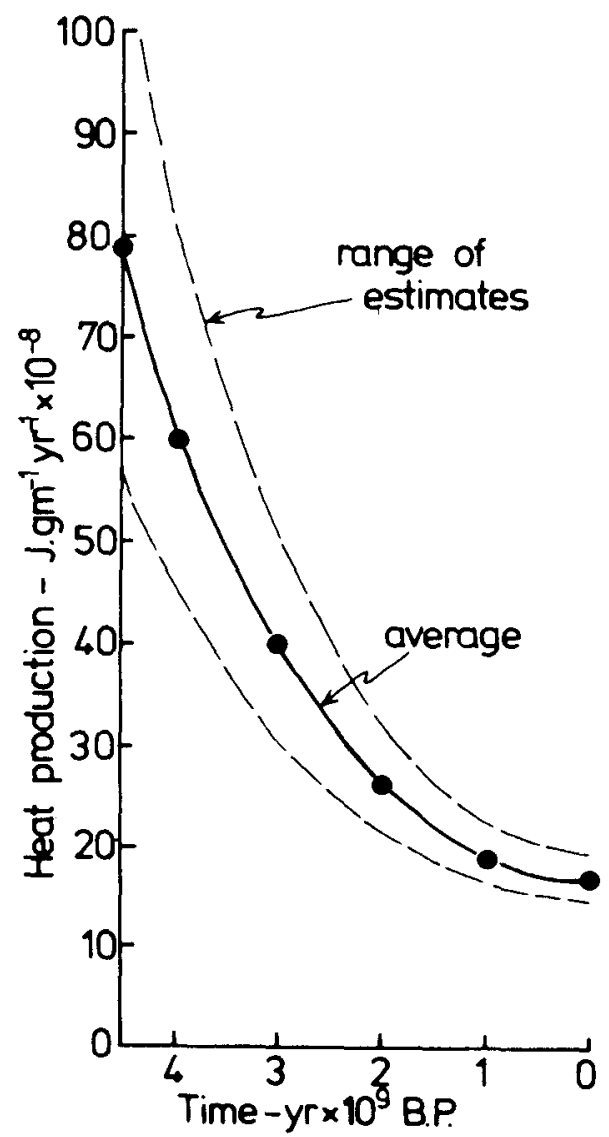

Figure 2: Total heat production through geological time (after W.H.K. Lee, 1967, from Burke et al., 1976). 
The half-life of $\mathrm{K}^{40}=1.250 \mathrm{Ga}, \mathrm{U}^{238}=4.46 \mathrm{Ga}, \mathrm{U}^{235}=0.70$ $\mathrm{Ga}$ and $\mathrm{Th}^{232}=14.0 \mathrm{Ga}$, and therefore the isotopes we are considering in the Precambrian are the same as those of today but at an earlier stage in their breakdown. Much of the heat production today is directly related to mantle convection and plate production; the long-term thermal and related tectonic evolution of the earth must be related to the life span of these heat-producing isotopes, which thus provide us with the link between the tectonics of the past and the present.

The two essential requirements for the operation of plate tectonics are, firstly, that mantle convection must allow the dissipation of heat in the construction of new oceanic lithosphere, and secondly, that the continental plates must be sufficiently rigid to allow lateral drift. These factors imply in turn that plate decoupling and subduction must operate. Is the Precambrian geological record consistent with these geophysical constraints?

\section{The Archaean}

Two types of tectonic regime formed in the Archaean until about $2.5 \mathrm{Ga}$ ago: granulite-gneiss belts and greenstonegranite belts.

\section{Granulite-gneiss belts}

Important belts of this type occur in NW Scotland, Greenland, Labrador, southern Africa (the Limpopo), southern India, and the Kola, Aldan and Anabar Shields of the U.S.S.R. Most belts went through a major thermal event in the period 2700 $3100 \mathrm{Ma}$ (Moorbath, 1976), but older rocks are known in West Greenland, Labrador and the Limpopo belt of southern Africa.

These belts contain three highly metamorphosed (amphibolite-to-granulite grade) rock suites:

a) About $5 \%$ of the gneisses contain alumino-silicate minerals, locally pass into mica schists and are, no doubt, of sedimentary origin;

b) Quartzo-feldspathic gneisses, which constitute about $85 \%$ of the present surface area, are largely tonalitic to granodioritic in composition. They are mostly well foliated, but locally they are less deformed and less foliated in lowstrain zones that have the form of elongate lenses up to ca. 1 $\mathrm{km}$ across, within which the tonalites and granodiorites are preserved in their original undeformed state. These rocks have calc-alkaline bulk compositions and are comparable to Cordilleran tonalites from the batholiths of the active continental margin of western North and South America (Tarney, 1976; Windley and Smith, 1976); c) Within the gneisses there are remains of layered igneous complexes up to $1-2 \mathrm{~km}$ wide which may consist of ultrabasic-gabbro or leucogabbro-calcic anorthosite. Wellpreserved examples are the Fiskenaesset complex in West Greenland, the Sittampundi complex in southern India and the Limpopo anorthosites (for references, see Windley, 1977), but many of the granulite-gneiss belts contain tens of $\mathrm{km}$ of layers of anorthositic rocks which in places are in the form of lenses and pods, being remnants of larger bodies broken up by the intruding tonalites.

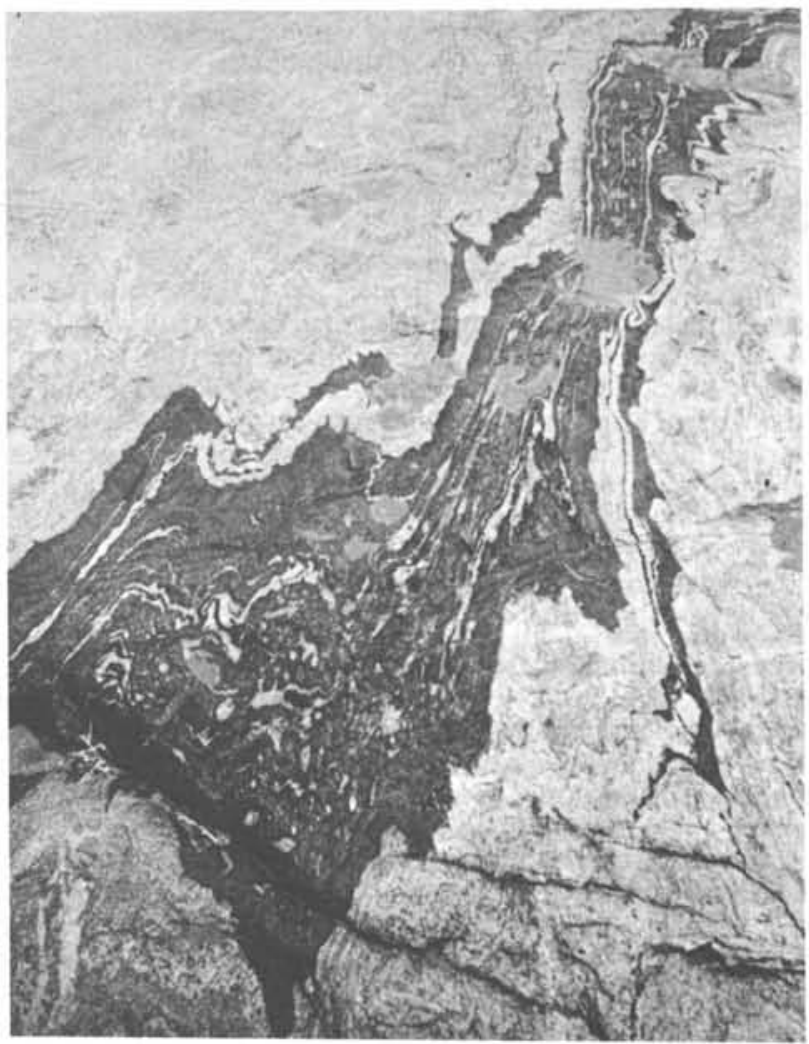

A folded amphibolite dyke in $3800 \mathrm{Ma}$ gneiss, Sand River, Limpopo mobile belt, South Africa.

There have been few attempts to explain the tectonic environment of the Archaean granulite-gneiss belts. Probably the most apposite is based on a comparison with the most deeply eroded batholiths of the Cordilleran fold belt of North and

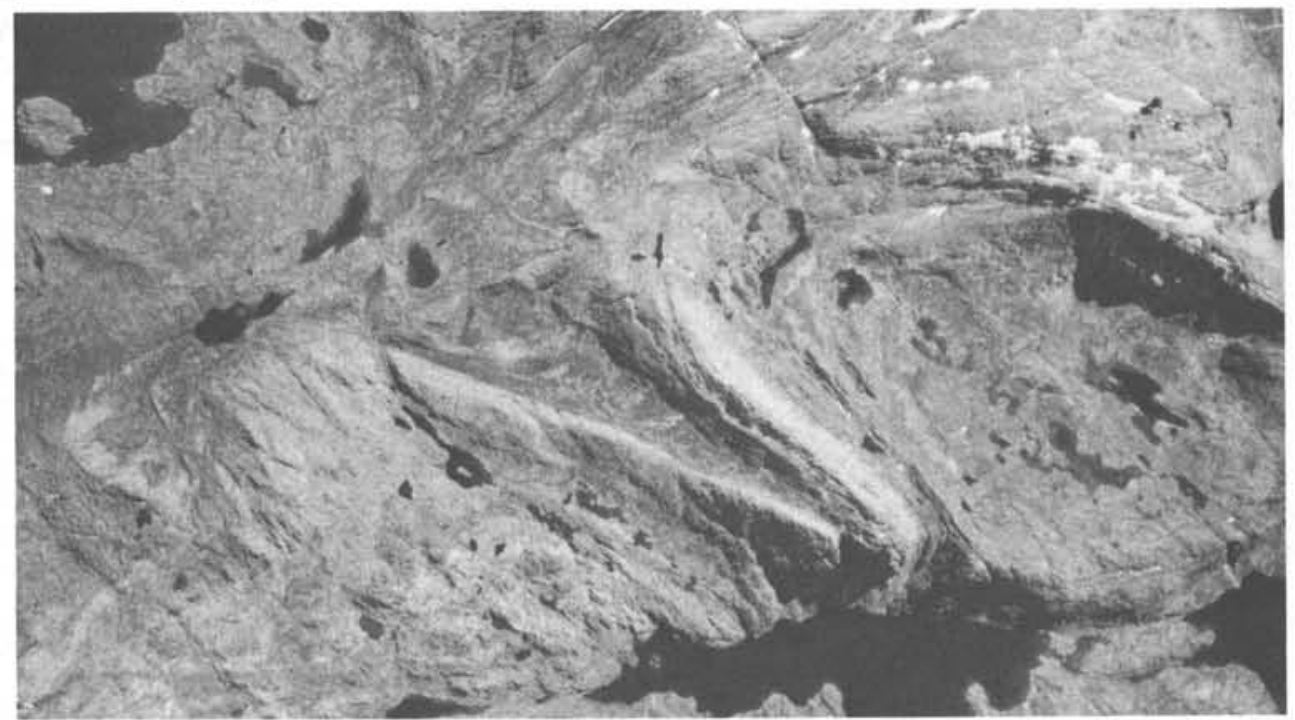

Folded white layers of the Fiskenaesset igneous complex (western Greenland) bordered by dark gneiss. (Copyright Geodetic Institute, Copenhagen, Denmark) 
South America, the geological and igneous geochemical features of which are remarkably similar to those of the granulite-gneiss belts in their pre-metamorphic and predeformed state. The most appropriate batholiths are in British Columbia, Chile and southern California, the first two having probably been eroded some $15-20 \mathrm{~km}$. Over $50 \%$ of these calc-alkaline batholiths consist of tonalite that has commonly been highly deformed into gneiss and within which there are many layered peridotite-gabbro-anorthosite (An $80^{-}$ An 100 ) complexes.

The Cordilleran tectonic environment developed above a subduction zone provides us with a mechanism for generating voluminous quantities of intrusive tonalitic material - and this solves one of the most important problems in Archaean petrogenesis. We know of no other tectonic environment capable of producing geochemical end products of such proportions.

\section{Greenstone-Granite Belts}

There are important greenstone belts in South Africa (especially Barberton Mountain Land), Rhodesia, the Yilgarn and Pilbara blocks of Western Australia, the Superior and Slave Provinces of Canada and Minnesota in the U.S.A., India (the Dharwar belts), and Finland. In most continents, the belts seem to have formed in the period $2.6-2.8 \mathrm{Ga}$ ago, but in Rhodesia they formed during three episodes - $3.6 \mathrm{Ga}$ (Sebakwian), 3.0 Ga (Lower Bulawayan), and $2.8-2.7 \mathrm{Ga}$ (Upper Bulawayan and Shamvaian), while in India the Dharwar belts have an age of $2.6-2.1 \mathrm{Ga}$.

Greenstone belts, whose area ranges from $40-250 \mathrm{~km}^{2}$ to $120-$ $800 \mathrm{~km}^{2}$, ideally have a synformal structure with a lowpressure greenschist regional metamorphism and associated prominent cleavage, are intruded by plutons ranging from tonalites to granites, and have three major stratigraphic units:

a) A lower group consists of pillow-bearing komatiitic ultramafic-to-mafic lavas. The magnesian peridotitic komatiites, which are restricted to the Archaean, represent high degrees of partial melting of mantle and probably result from localized high heat fluxes. The less magnesian basaltic komatiites have bulk compositions broadly resembling those of modern mid-oceanic ridge basalts and similar komatiites; they were erupted in the Phanerozoic in connection with basaltic volcanism.

b) Andesites and silicic volcanics of calc-alkaline type make up a central group. Their trace and rare earth elements are very similar to those in modern island arc and Andean volcanics.

c) An upper group comprises conglomerates, sandstones and turbidites, and chemically precipitated banded iron formations, cherts and limestones. The clastic sediments were derived partly from continental, granitic gneiss terrains and partly from volcaniclastic, volcanic arc-type belts.

The many tectonic models proposed to explain the formation of greenstone belts are summarized in Windley (1977). Most plausible is the one based on the remarkable similarity of greenstone belts with Phanerozoic closed marginal basins. On the east side of the Pacific, the marginal basins that originally formed by extension behind the Cordilleran arc, closed by movement of the arc towards the continent. Examples are found NW of the Sierra Nevada (Palaeozoic) in California (Burke et al., 1976), and the "Rocas Verdes" Mesozoic complex in southern Chile (Tarney et al., 1976). Palaeozoic greenstone belts occur in the Round Pond area of Newfoundland, Canada (Burke et al., 1976), and in the Lachlan fold belt of SE Australia (Crawford and Keays, 1978); there are early Proterozoic (ca. 1.75 Ga) belts in the Amisk Group in Canada (Bell et al., 1975).

The modern marginal basins do not differ in any significant degree from the Archaean greenstone belts - that is, in their gross stratigraphic groups and lithologies, in the geochemistry of ultramafics, oceanic-type basalts, island arc-type andesites, intruding tonalites and granites, and in the nature of the late sediments. The tectonic environment is ideal for the close association of oceanic- and arc-type volcanics, clastic sediments derived from a continental terrain and a volcanic arc, and tonalite-granite plutons of Andean type. No other tectonic model can so satisfactorily provide a mechanism for the rifting and extension of the basins and their closure by movement of arc towards continent, and also for the mutual relationships of the diverse rock suites and their geochemical characteristics.

\section{Archaean-Proterozoic Boundary}

The Archaean-Proterozoic boundary has major tectonic significance for continental evolution. It records the change from widespread and episodic plate creation and collision giving rise to thicker, more extensive and more stable continental plates by the early Proterozoic.

The Archaean-Proterozoic boundary was most probably diachronous and transitional, extending over several hundred million years from about $2.7 \mathrm{Ga}$ to $2.3 \mathrm{Ga}$. The new period of stability, typical of the Proterozoic, is marked by the first appearance of extensive dolerite dyke swarms, alkaline igneous rocks, kimberlites, aulacogens (or failed rift arms) and cratonic cover sequences. Mobile belts, ubiquitous in the Archaean, became confined to narrow linear zones at cratonplate margins, thus enabling intra-plate continental-cover sequences to be deposited and continental intra-plate magmatism to develop. The Archaean-Proterozoic tectonic change reflected the considerable decrease in radiogenic heat production over this time period.

Ma

TABLE 1

450

750

Pan-African collisional mobile belts

1000 Grenville-Moine-Dalslandian collisional mobile belt

1400- Anorthosite-granite suite

1500 Abortive rifting of large continental mass(es)

1800- Early Proterozoic mobile belts. Wilson cycle

2100 starts here

Uplift and erosion

Formation of thick and stable continental plates

2700- Continental growth in several episodes throughout

3800 Archaean time giving rise to granulite-gneiss and greenstone belts

Table 1: Some main events in Precambrian tectonic evolution.

\section{Early to Mid-Proterozoic Collisional Geosynclines and Mobile Belts}

Recent data suggest that several geosynclines or mobile belts were created by some kind of plate collision in the period 2.1 - 1.7 Ga ago:

a) The Coronation Geosyncline formed in NW Canada about $2.1-1.75 \mathrm{Ga}$ ago as the early part of the Wopmay Orogeny which formed a complete Wilson cycle (Hoffman, in press). All the major tectono-magmatic-stratigraphic events from early oceanic accretion, through Cordilleran activity, to Himalayan-type terminal collision are decipherable here. The relationships suggest that tectonic processes (as we understand them today) were in operation by the early Proterozoic in NW Canada.

b) Tapponnier and Molnar (1976) demonstrated that the major wrench faults of Asia can be interpreted in terms of slip-time theory as the result of the northward indentation of India into Asia. Similar wrench fault patterns led Gibb (1978) to suggest that the Slave craton had indented southeastwards into the Churchill Province of Canada; Watterson (1978) 
proposed that similar sets of shear belts in central West Greenland were the result of a northward continental collision in South Greenland, which was responsible for the contemporaneous formation of the Ketilidian mobile belt and the Julianehaab batholith.

Palaeomagnetic data suggest that the Circum-Ungava Geosyncline is most probably located along a collisional suture between the Superior and Churchill Provinces (Cavanaugh and Seyfert, 1977), and regional gravity profiles were used by Kearey (1976) to define the continental margin thickened by ductile flow of the overriding northern plate.

c) In southern Finland there is a belt of $1.7-1.9 \mathrm{Ga}$ old trondhjemitic gneisses in the Svecofennian mobile belt; they contain hornblende gabbro complexes and a series of later granites, the potash content of which increases systematically towards the north. Hietanen (1975) compared petrogenetic development of this rock suite with that of the Sierra Nevada batholith in California, with its hornblende gabbro complexes and its west-to-east change from sodic tonalites to potassic granites.

d) There are eclogite lenses containing glaucophane in the 1.7 - 1.8 Ga old gneisses of SW Norway (Krogh, 1977). From the composition and stability fields of coexising minerals, it is estimated that the eclogites formed at $30-40 \mathrm{~kb}$ pressure. Such exceedingly high pressures can most readily be related to incorporation of mantle material into the continental crust along a major suture.

\section{Mid-Proterozoic Rifting and Magmatism}

Anorthosite-rapakivi granite suites were intruded in Scandinavia about 1.7 Ga and in North America about $1.5-1.4$ $\mathrm{Ga}$ ago. The anorthosites have andesine-labradorite and the granites contain potash feldspar and iron-rich minerals such as fayalite, and are associated with ferrodiorites. In an extensive review, Emslie (1978) concludes that the suite represents the product of bimodal magmatism generated by partial melting of deep crustal rocks, and intruded in an anorogenic environment in the early states of major intracontinental rifting in the mid-Proterozoic.

In the later stages, the rocks are locally associated with alkaline igneous complexes which were intruded in graben that controlled the outpouring of rhyolitic lavas and the sedimentation of continental sandstones. Significantly, the rock associations are similar to the anorogenic Palaeozoic "Younger Granite" complexes of Nigeria and Niger, which comprise fayalite granites, labradorite anorthosites, gabbros, syenites and alkaline granites. Also comparable are the Permian larvikites of the Oslo Graben, and the CretaceousJurassic White Mountain Series of New Hampshire, U.S.A.

\section{Late Proterozoic Collisional Mobile Belts}

1. The Grenville belt in eastern Canada and the Dalslandian belt in southern Norway and Sweden, both of which formed ca. 1.0 Ga ago, are increasingly interpreted as being the result of continental collision. Palaeomagnetic data (Irving et al., 1974) support the idea of Dewey and Burke (1973) that the Grenville belt is the deeply eroded product of a Himalayan-type collision. Basic-ultrabasic complexes in the Madoc-Bancroft area may define a cryptic suture (Chappell et al., 1975), and trace element data of low-K tholeiites and andesites near Bancroft are consistent with production in a volcanic arc (Condie and Moore, 1977). The Dalslandian belt contains several low-angle thrusts on which slabs of crustal thickness have been piled one upon another. The possible suture is outlined by a N-S trending belt of thrust stacks 200 $-300 \mathrm{~km}$ in length and $50 \mathrm{~km}$ wide (Berthelsen, 1976).

2. The Pan-African and Braziliano belts reached their peak of orogenic activity in the period $0.65-0.4 \mathrm{Ga}$. There has been considerable success in establishing geological relationships which point cogently towards a plate tectonic mode of development. Recent literature reports the following features: there are ophiolites with serpentinites, gabbros,

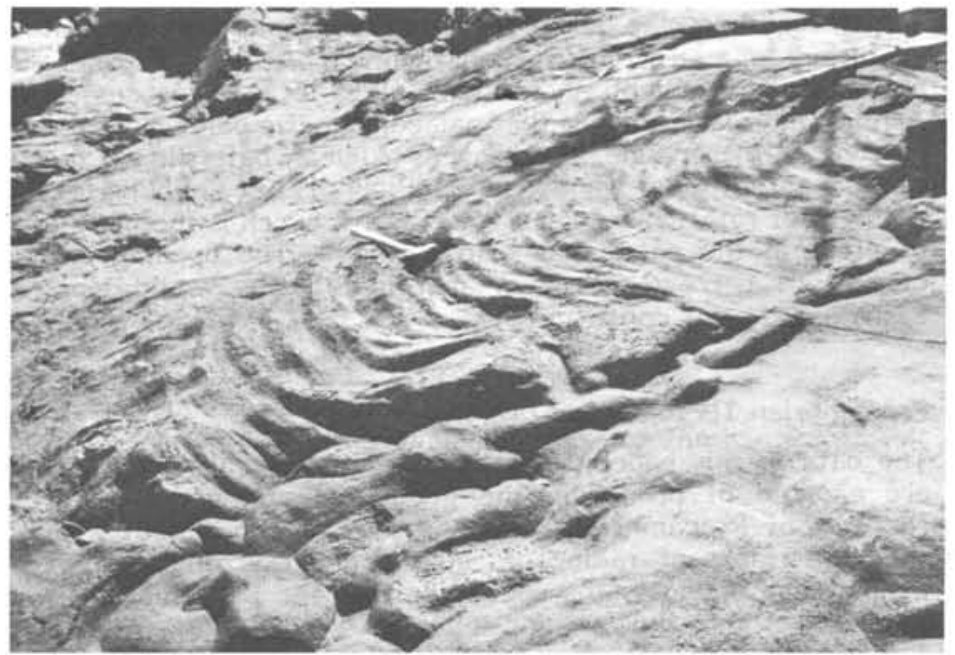

The ropy top of 1000 Ma lava flow in the Keweenawan Series, Duluth, U.S.A.

sheeted dykes (dolerites) and basalts in the Arabian Shield and NE Africa. Shackleton (1976) suggested the presence of a great many possible ophiolite complexes throughout Africa and Brazil. In NE Sudan, ophiolites are associated with rhyolitic-andesitic pyroclastics and intruded by calc-alkaline batholithic granites. In southern Libya, the Ben Ghnema batholith exhibits a lateral composition change from tonalite and granodiorite to adamellite and granite, like the west-toeast variation across the Sierra Nevada batholith. In Morocco there is a continental margin sequence of limestone and quartzites, alkaline basalts related to early stages of continental fragmentation, and stratiform copper deposits associated with off-shore shale deposition. In the Hoggar of Algeria there are andesites, dacites and calc-alkaline batholiths formed in connection with island arc-Andean subduction and high-level nappes, and syn-kinematic granites related to crustal thickening and crustal melting during continental collision. In Egypt there are intrusions with porphyry-type $\mathrm{Cu}-\mathrm{Mo}$ mineralization and Kuroko-type massive sulphides. The geochemistry of calc-alkaline dacites and rhyolites in Nigeria is consistent with the existence of a suture there, and the presence of glaucophane-bearing blueschists in the Gariep belt of Namibia can reliably be explained by plate tectonic mechanisms.

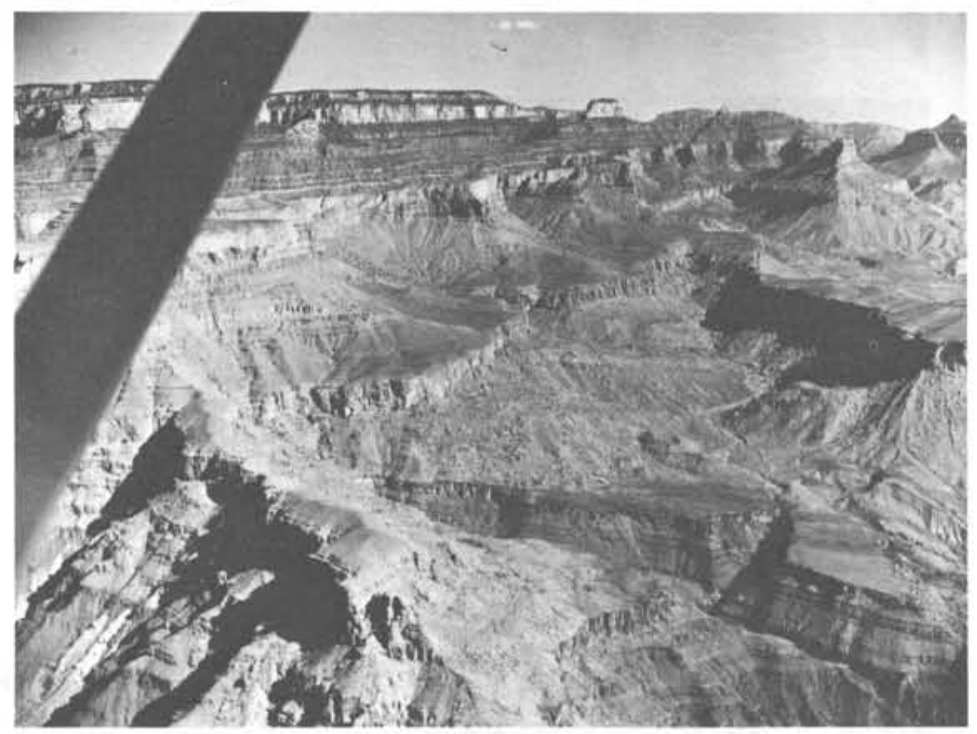

Late Precambrian sediments overlain unconformably by Palaeozoic sediments in the Grand Canyon, Arizona, U.S.A. (Photo courtesy the late Parker Hamilton) 
Taken together, the above evidence suggests that crustal evolution in many Pan-African mobile belts can be interpreted very reasonably in terms of plate tectonic processes. A final important point is that palaeomagnetic poles from the cratons on either side of some Pan-African belts lie on the same apparent polar wander paths (Piper, 1973), implying less than $15^{\circ}$ of rotation between the cratons, which is the margin of error in the palaeomagnetic method. The opening and closure of narrow oceans or marginal basins would most easily satisfy this constraint.

\section{Precambrian Tectonics}

The data in this paper suggest that plate tectonic processes are capable of producing the geological and geochemical features of Precambrian belts and they are consistent with the constraints of radiogenic heat production and palaeomagnetism. Clearly, the second half of the Precambrian is easier to analyze and interpret than the first half, because the Archaean-Proterozoic boundary represents the onset of modern-style plate tectonic mechanisms. Nevertheless, there are no reasons to believe the earth's dynamo was different in type in the Archaean than later on; most reasonably, it was merely at an earlier stage of development.

Viewed in historical perspective, it is not surprising that attempts to describe the evolution of Precambrian belts in terms of plate tectonic mechanisms are increasing, firstly as more and more is being understood about the geological relationships in modern Cordilleran and Himalayan (or Alpine) fold belts, and secondly, as more Precambrian geologists realize the relevance and application of modern types of "orogenesis" to Precambrian mobile belts. We are at a stage when the lessons learned from our new understanding of the geology of accretionary and collisional continental margins must be applied to Precambrian belts: the old belts will be a test of the new ideas.

\section{References}

Bell, K., Blenkinsop, J., Moore, J.M., 1975, Evidence for a Proterozoic greenstone belt from Snow Lake, Manitoba: Nature, v. 258, p. 698-701.

Berthelsen, A., 1976, Himalayan tectonics: a key to the understanding of Precambrian shield patterns, in Coll. intern. du CNRS No. 268: Ecologie et Géologie de I'Himalaya, p. 61-67.

Bickle, M.J., 1978, Heat loss from the earth: a constraint on Archaean tectonics from the relation between geothermal gradients and the rate of plate production: Earth Planet. Sci. Lett., v. 40, p. 301-315.

Burke, K., Dewey, J.F., Kidd, W.S.F., 1976 , Dominance of horizontal movements, arc and microcontinental collisions during the later permobile regime, in Windley, B.F. (ed.), The Early History of the Earth: Wiley, London, p. 113130.

Burke, and K., Kidd, W.S.F., 1978, Were Archaean continental geothermal gradients much steeper than those of today?: Nature, v. 272, p. 240-241.

Cavanaugh, M.D., and Seyfert, C.K., 1977, Apparent polar wander paths and the joining of the Superior and Slave Provinces during early Proterozoic time: Geology, v. 5, p. 207-211.

Chappell, J.F., Brown, R.L., Moore, J.M., 1975, Subduction and continental collision in the Grenville Province of South Eastern Ontario: Geol. Soc. Am. Abstr. with Prog., v. 7, p. 733.

Condie, K.C., and Moore, J.M., 1977, Geochemistry of Proterozoic volcanic rocks from the Grenville Province, eastern Ontario: Geol. Ass. Can. Sp. Pap., v. 16, p. 149-168.

Crawford, A.J., and Keays, R.R., 1978, Cambrian greenstone belts in Victoria: marginal sea-crust Moorbath, S., 1976, Age and isotope constraints for slices in the Lachlan fold belt of Southeastern Australia: Earth Planet. Sci. Lett., v. 41 , p. 197 208. wey, J.F., and Burke, K.C.A., 1973, Tibetan, Piper, J.O.A., 1973, Geological interpretation of Variscan, and Precambrian basement reactivation; palaeomagnetic results from the African products of continental collision: 3. Geol., ४. 81,

P. 683-692.
Emslie, R.F., 1978, Anorthosite massifs, rapakivi granites and late Proterozoic rifting of North
grae, R.F. 1978, Anorthosite massifs, rapakivi America: Precam. Res., v. 7, p. 61-98.

Gibb, R.A., 1975, Slave-Churchill collision tectonics: Nature, v. 271, p. 50-52.

Hietanen, A., 1975, Generation of potassium-poor magmas in the northern Sierra Nevada and the Svecofennian of Finland: J. Res. U.S. Geol. Surv., v. 3, p. 631-645.

Hoffman, P., in press, A Wilson cycle of early Proterozoic age in the Canadian Shield: Geol. Ass. Can. Sp. Pap.

Irving, E., Emslie, R.F., Veno, H., 1974, Upper Proterozoic palaeomagnetic poles from Laurentia and the history of the Grenville structural province: J. Geophys. Res., v. 79, p. 5491-5502.

Kearey, P., 1976, A regional structural model of the Labrador Trough, northern Quebec, from gravity studies, and its relevance to continent collision in the Precambrian: Earth Planet. Sci. Lett., v. 28, p. $371-378$.

Krogh, E.J., 1977, Evidence of a Precambrian Nature, $v 267, p, 17-19$.

McElhinny, M.W., 1973, Palaeornagnetism and plate tectonics: Cambridge Univ. Press, $358 \mathrm{p}$. (eds.), Implications of Continental Drift to the The Earth Sciences: Academic Press, London, v. 1, p. 19-32.

Shackleton, R.M., 1976, Possible late-Precambrian ophiolites in Africa and Brazil: 20 th An. Rep. Res. Inst. Afr. Geol., Univ. Leeds, p. 3-7.

Tapponnier, P., and Molnar, P., 1976, Slip-line field theory and large-scale continental tectonics: Nature, v. 264 , p. $319-324$

Tarney, J., 1976, Geochemistry of Archaean highgrade gneisses with implications as to the origin and evolution of the Precambrian crust, in Windley, B.F. (ed.), The Early History of the Earth: Wiley, London, p. 405-417.

Tarney, J., Dalziel, I.W.D., de Wit, M.J., 1976, Marginal basin 'Rocas Verdes' complex from S. Chile: a model for Archaean greenstone belt formation, in Windley, B.F. (ed.), The Early History of the Earth: Wiley, London, p. 131-146.

Watterson, J., 1978, Proterozoic intra-plate deformation in the light of SE Asian neotectonics: Nature, v. 273 , p. 636-640.

Windley, B.F., 1977, The Evolving Continents: Wiley, London, $385 \mathrm{p}$.

Windley, B.F., and Smith, J.V., 1976, Archaean highgrade complexes and modern continental margins: Nature, v. 260, p. 671-675.

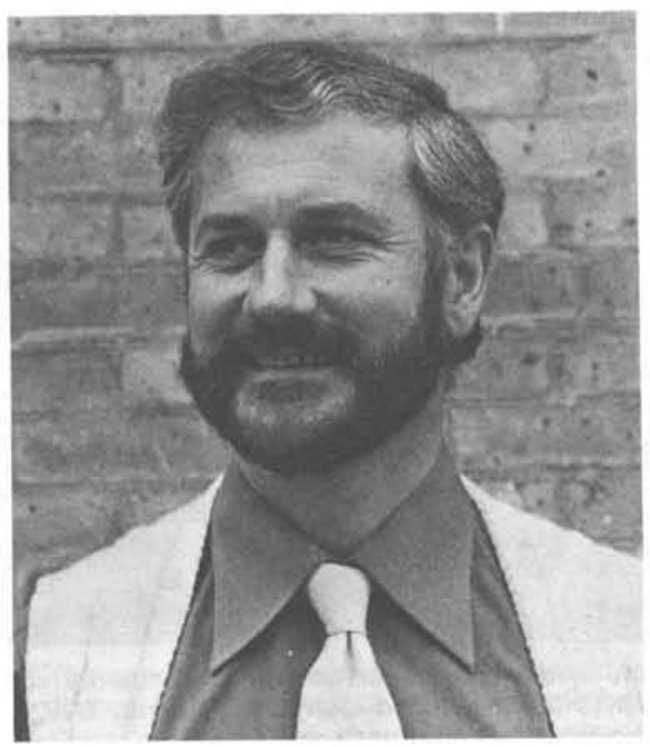

ABOUT THE AUTHOR: Reader in the Department of Geology, University of Leicester, U.K., and author of the well-known book "The Evolving Continents" (1977), Dr. Brian F. Windley is a Council member of the Geological Society of London and recipient of the Society's Bigsby Medal in 1977. Dr. Windley is the U.K. correspondent for IGCP Project 92: "Archean Geochemistry". 